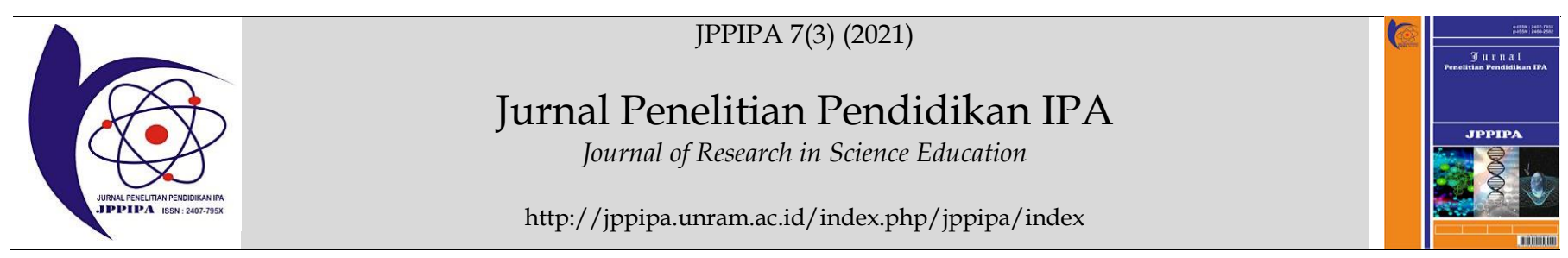

\title{
Developing Instagram-Based E-Poster for Learning the Concept of Alkaline Group of Periodic Table
}

\author{
Muhammad Nazar ${ }^{*}$, Ratu Fazlia Inda Rahmayani ${ }^{1}$, Diwana Aida ${ }^{1}$, Kana Puspita ${ }^{1}$ \\ 1 Universitas Syiah Kuala, Department of Chemistry Education, Banda Aceh, Indonesia.
}

DOI: $10.29303 /$ ippipa.v7i3.733

\section{Article Info}

Received: May 5th 2021

Revised: July 10th, 2021

Accepted: July 14th, 2021

\begin{abstract}
This research aimed at developing e-poster as learning media, analyzing how students respond to the e-posters uploaded to Instagram. This R\&D research utilized an ADDIE model of development consisting of five stages: analysis, design, development, implementation, and evaluation. The research took place during even semester at the Department of Chemical Education, Faculty of Education and Teacher Training, Universitas Syiah Kuala. A total of twenty-four students (4 male and 20 female) who enrolled in the course of "elements and compounds of primary groups" voluntarily took part in the research subjects. We collect the data using the following instruments: A validity assessment form, a questionnaire for students, and an active Instagram account necessary for uploading the contents and monitoring students' activity on the platform. The results show that the validity score of e-posters was $97.5 \%$, and $89 \%$ of students responded positively to the media, and the vast majority of students would prefer to learn using e-posters in the future. The findings indicated that e-posters could contribute as alternative learning media to help students understand the concept of alkali group elements.
\end{abstract}

Keywords: Instagram; Social Media; E-poster; Alkaline group

Citation: Nazar, M., Rahmayani, R., Aida, D., \& Puspita, K. (2021). Developing Instagram-Based E-Poster for Learning the Concept of Alkaline Group of Periodic Table. Jurnal Penelitian Pendidikan IPA, 7(3), 458-463. doi:https://doi.org/10.29303/jppipa.v7i3.733

\section{Introduction}

Abstract characteristics of chemistry such as chemical elements require teachers to be creative in dealing with the learning process by applying various methods and media, including social media. According to Asmara (2015), elemental chemistry subject matter is one part of the concept that has the potential to bore students because it contains conceptual, contextual, descriptive theories or is often referred to as memorization material. Due to the characteristics of the material like this, students are less interested in learning, resulting in low learning outcomes.

Usually, the learning process carried out in the main class elements and compounds lectures, especially in the alkaline group elements material, is still dominated by PowerPoint media and printed books. In addition, students usually study only in class so that they are less independent in learning. Therefore, it is necessary to develop media that can encourage students to study chemistry independently. One of the innovative media that can be used especially in the chemical materials of alkaline group elements, is posters.

Posters are a visual learning medium that combines images and text and is designed to be attractive to be conveyed to the audiences. The purpose of the poster is to inform readers about information that is packaged in shorter, concise, clear, and interesting words. The poster is identical to the picture said on paper. However, poster production may seem relatively simple and cheap, but it is quite expensive (Ilic \& Rowe, 2013). In addition, printed posters can be damaged and torn. Therefore, we developed e-posters posted on Instagram because Instagram is a social media that is currently popularly used by young people, especially students. After all, Instagram posts can be accessed at 
any time to avoid damage to posters and their wider distribution on social networks.

The choice of Instagram as a means to deliver subject matter is not without reason, several factors that underlie the selection of Instagram are that Instagram is a photo-sharing application that is popular among both young and adult groups, has wide users with various backgrounds, and most of the content can be accessed for free. Although there is educational content on Instagram in general, content specific to one particular topic, such as chemistry, is very rare. (Irwandani \& Juariyah, 2016) stated that based on search results for popular keywords on Instagram, it was concluded that educational, science, and similar content were very rarely found.

Previous research has shown that website-based e-poster media can increase student motivation and activeness in learning and make it easier for students to understand material sources of energy and their uses. Research conducted by (Nugroho et al., 2017) also shows that physics e-posters uploaded on social media Instagram can increase learning motivation and can be used as a source of independent learning. (Handayani, 2016) reported successful implementation of Instagram as a learning tool.

In this research, we developed an E-Poster for Alkali Group Element Material and posted it on Instagram. The results of the posts were distributed to students who were taking lectures, and they were asked to give their responses after studying the alkaline element material through Instagram media.

\section{Method}

This is research and development (R\&D), which uses the ADDIE model, which has five stages: analysis, design, development, implementation, and evaluation. The research was conducted at the Faculty of Teacher Training and Education, Syiah Kuala University, Banda Aceh, during the even semester of the 2019-2020 academic year. The research subjects were 24 students of the Department of Chemical Education, Syiah Kuala University, who enrolled in Primary Element Groups, consisting of 4 male students and 20 female students.

Data was collected using several instruments such as a questionnaire to analyze the poster media's needs and determine the platform for its distribution. Students $(\mathrm{N}=24)$ were asked to answer 11 questions regarding their experience enrolling in the Primary element groups course, especially using learning media during the course work. In addition, media feasibility assessment sheets were also used to validate e-posters and student response sheets to examine students' thoughts about eposters that have been developed.

\section{Result and Discussion}

\section{Need Analysis}

Need analysis is a crucial part of e-poster development. Through this stage, we revealed the need for an e-poster posted on Instagram based on respondents' requirements and experience in their previous class of primary group elements course. Eleven questions were asked to students, and the answers are displayed in table 1.

Table 1. Students' responses to the need for Instagram based e-poster

\begin{tabular}{|c|c|c|c|}
\hline \multirow[t]{2}{*}{ No } & \multirow[t]{2}{*}{ Questions } & \multicolumn{2}{|c|}{ Answers $(\mathrm{N}=24)$} \\
\hline & & Yes (\%) & No (\%) \\
\hline 1 & $\begin{array}{l}\text { Did you use certain learning } \\
\text { media in learning the concept } \\
\text { of Alkaline Group Element? }\end{array}$ & 95.8 & 4.2 \\
\hline 2 & $\begin{array}{l}\text { What are frequently used } \\
\text { learning media by the } \\
\text { lecturer in this course? }\end{array}$ & See F & ure 1 \\
\hline 3 & $\begin{array}{l}\text { Did the concept in the } \\
\text { textbook or PowerPoint slide } \\
\text { attracted you to learn the } \\
\text { concept of alkaline metal? }\end{array}$ & 91.7 & 8.3 \\
\hline 4 & $\begin{array}{l}\text { Are you interested in using } \\
\text { posters in learning? }\end{array}$ & 95.8 & 4.2 \\
\hline 5 & $\begin{array}{l}\text { Do you prefer to learn using } \\
\text { e-posters instead of printed } \\
\text { posters? }\end{array}$ & 95.8 & 4.2 \\
\hline 6 & $\begin{array}{l}\text { Are you an active user of } \\
\text { Instagram? }\end{array}$ & 95.8 & 4.2 \\
\hline 7 & $\begin{array}{l}\text { Do you prefer Instagram than } \\
\text { Facebook, Twitter, Pinterest, } \\
\text { or line? }\end{array}$ & 91.7 & 8.3 \\
\hline 8 & $\begin{array}{l}\text { Do you consider using the } \\
\text { Instagram posts as an } \\
\text { alternative } \\
\text { resource? }\end{array}$ & 70.8 & 29.2 \\
\hline 9 & $\begin{array}{l}\text { When you are using } \\
\text { Instagram, do you frequently } \\
\text { find a chemistry poster? }\end{array}$ & 33.3 & 66.7 \\
\hline 10 & $\begin{array}{l}\text { Have you ever found the } \\
\text { specific subject of alkaline } \\
\text { metal on Instagram? }\end{array}$ & 12.5 & 87.5 \\
\hline 11 & $\begin{array}{l}\text { Do you consider that } \\
\text { Instagram is suitable to be } \\
\text { utilized as a learning media } \\
\text { for the concept of alkaline } \\
\text { metal? }\end{array}$ & 100.0 & 0.0 \\
\hline
\end{tabular}

Table 1 shows the closed questionnaires answered by 24 students responding to their need for an e-poster. When asked about using learning media in the classroom, the vast majority of students said that the lecturer pays a lot of attention to aid students in learning by using media. This question was furthered extended 
to emphasize frequently used learning media, and the result is depicted in figure 1.

The table also revealed that most students prefer to use Instagram as they are active users. When asked about their preference in using several social media, most of them would rather pick Instagram instead of other platforms such as Facebook, Pinterest, or Twitter. Furthermore, when asked about how frequently they would find chemistry-related posts on Instagram, more than a half $(66,7 \%)$ said no. When the question emphasized the specific concept studied in this research, even more students $(97,5 \%)$ said never find the posters on Instagram. Therefore, when asked whether they would consider Instagram as a proper social media to deliver chemistry concepts, all students agreed to the idea.

The result of the analysis was then used as consideration for developing the e-posters on Instagram. Need analysis is required at a very early stage of material or learning media development. Suppose we fail to conduct a need analysis. In that case, good products cannot be achieved because a need analysis benefits students or teachers and is important in improving the quality of a developed learning media (Darici, 2016).

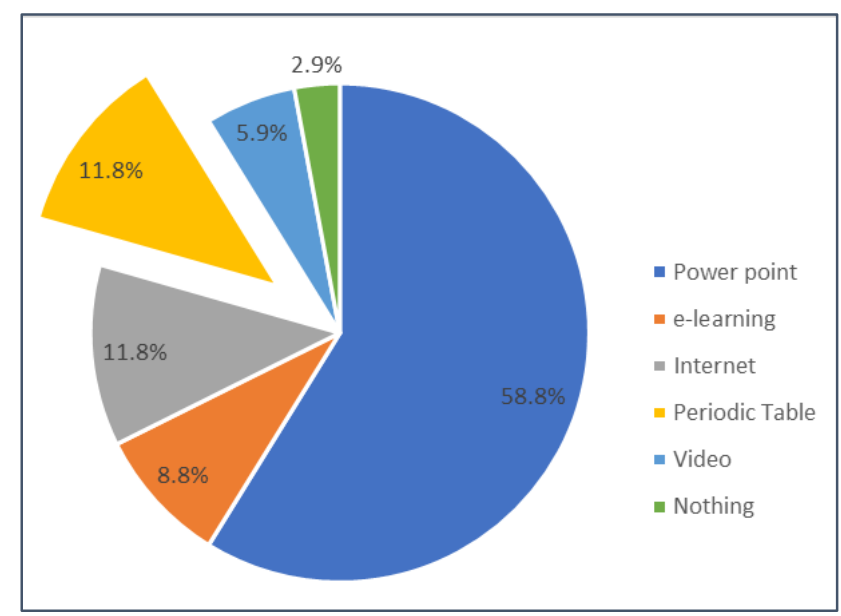

Figure 1. Frequently used learning media in the course of primary group elements (based on students' answers for question no. 2) (See Table 1)

Figure 2 shows learning media or learning resources that lecturers often used in the classroom. The most dominant media used was the Microsoft PowerPoint slide. While lecturers in teaching less frequently used video and e-learning. PowerPoint has widely used presentation software in many fields, including education. The simplicity and practicality of the PowerPoint have triggered massive use of this program around the globe. Many educational institutions at any level have been using this Microsoft's program for decades because PowerPoint enables professional look presentations at an affordable cost(Jones, 2003).

\section{E-poster Design}

At this stage, we designed e-posters by formulating material items that are in accordance with the Semester Learning Plan (RPS) of the main group elements and compounds course, especially in the concept of alkaline group elements. A literature study was carried out at this stage to collect information related to the alkaline group elements material from university basic chemistry textbooks. The list of material to be displayed on the e-poster consisting of six posters can be seen in Table 2 .

Table 2. List of concepts consisted in the posters

\begin{tabular}{ll}
\hline No. & Concepts \\
\hline 1 & History of an alkaline group of elements \\
2 & Physical properties of the alkaline elements \\
3 & Chemical properties of the alkaline elements \\
4 & Alkaline metal extraction \\
5 & Alkaline metal synthesis \\
6 & Daily life benefits of alkaline metal \\
\hline
\end{tabular}

There were six posters designed for further development by considering the scope of the concepts that coherent with the learning plan. All designs went through revisions prior to implementation and dissemination via Instagram. Figure 3 shows the initial design of a poster.

\section{SIFAT-SIFAT FISIKA UNSUR GOLONGAN ALKALI}

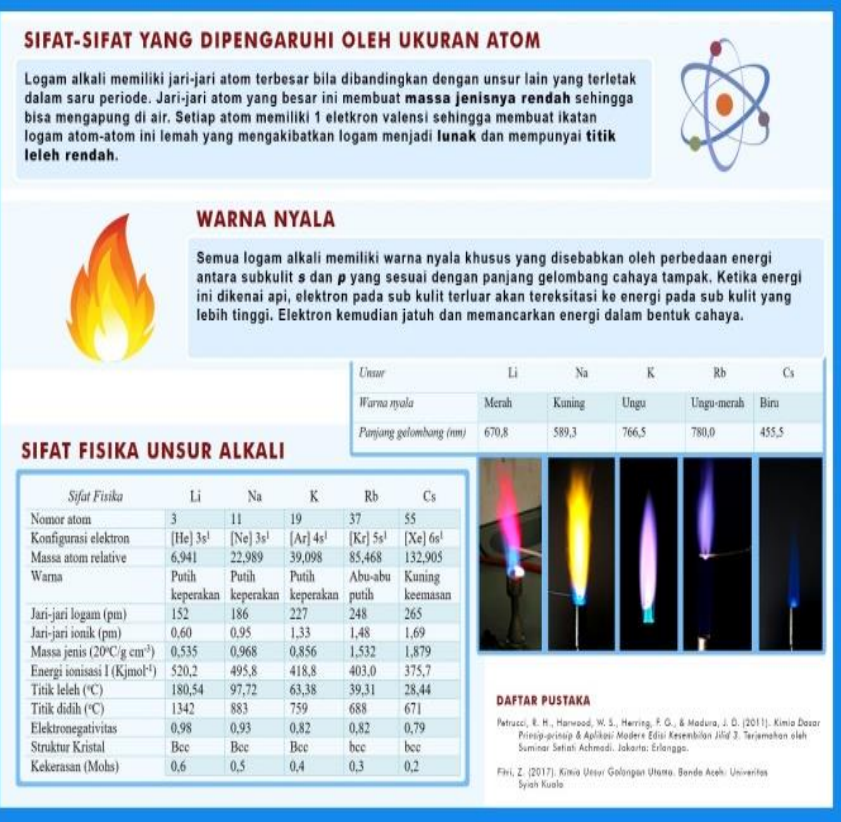

Figure 2. The initial design of a poster 


\section{E-Poster Development}

The development stage is the product realization stage. Through this stage, the media was prepared to fit a previously proposed design. Development of e-poster media was also carried out in accordance with suggestions of expert validators. Some suggestions generally include sentence effectiveness, letter size suitability, and image selection according to the material's content.

We spent a couple of weeks finishing the development of the e-posters because the designs required revisions and validation. After the final designs were corrected and commented by reviewers, the eposters were posted to Instagram, and the links were distributed to the students. The final design of the first poster is depicted in figure 3 .

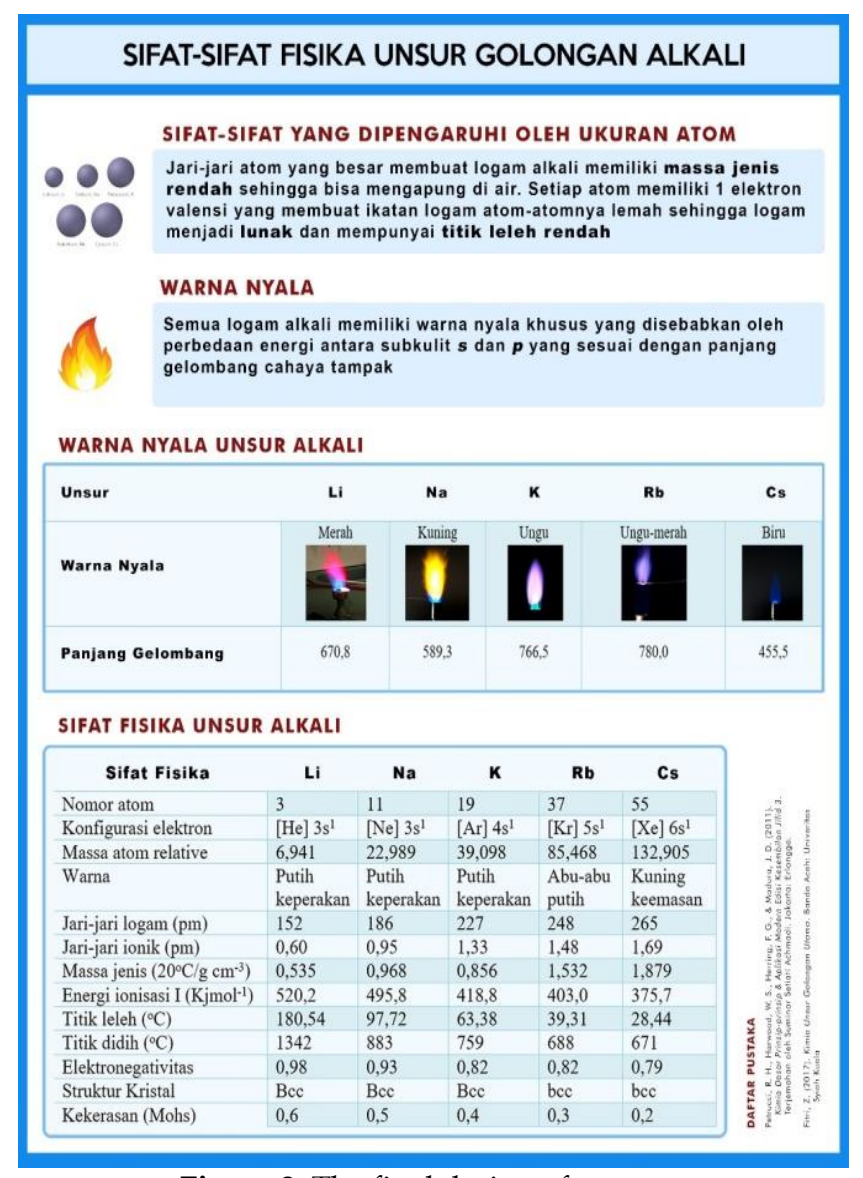

Figure 3. The final design of a poster

\section{Validation of e-posters}

Two experts validated the e-poster designed for learning materials on alkali metals before it was used as lecturing material. The validation covered four aspects, including design, content, images, and language. The validation results are shown in Figure 4.

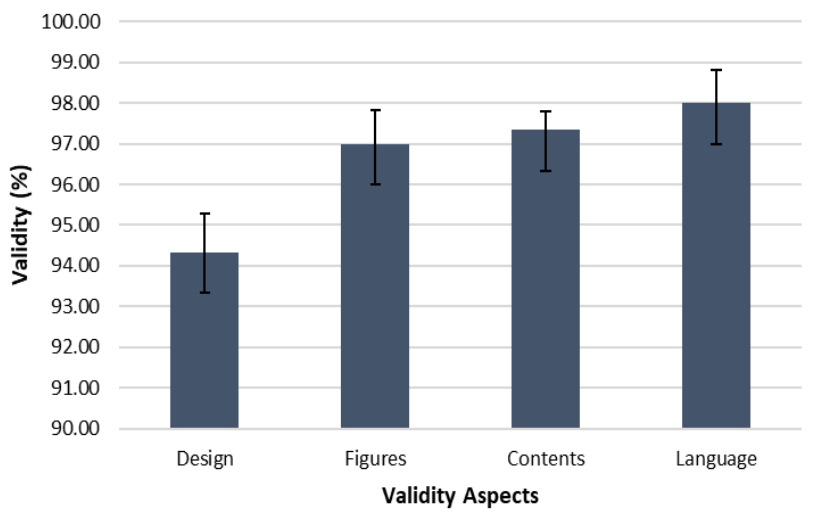

Figure 4. Validity of the e-posters in four different aspects

The validation carried out in this study was expert judgment involving experts in the field of instructional media as well as chemical content. Figure 1 shows the results of the validation carried out by the experts. The validation results on four aspects, including design quality, image quality, chemical content quality, and linguistic aspects, showed a high level of validity. The graph shows that the linguistic aspect shows the highest validity value $(98.0 \%)$ while the lowest $(94.5 \%)$ design aspect.

Validation of a product, especially the learning media used in learning, is very important because a medium conveys scientific messages. Failure to produce valid products, especially in the aspects of language and content, will have a negative impact on learning outcomes and can even lead to misconceptions. If students experience misconceptions due to invalid learning media in terms of content, learning in the classroom cannot achieve its goals.

According to (Sobah CH et al., 2019), Misconceptions could be encountered from various sources such as books, learning media, social media, and even teachers can cause students to experience misconceptions if they teach wrong concepts. The term "misconception" refers to a hypothesis that is incompatible with scientific orthodoxy and fails to properly describe observed scientific phenomena. (Dellantonio \& Pastore, 2020). Therefore, the accuracy of the concepts contained in a learning resource or learning media is very important to note.

\section{Implementation}

After final designs were obtained, all posters had been validated with a high score of validity with overall scores greater than $94 \%$. The posters were then posted on Instagram. The links of each posted poster were given to all students so they can start to learn the concepts through Instagram. After two weeks, the number of likes was recorded, and the students were asked to post the comments and respond to the posters' quality. Their responses were recorded by using a questionnaire 
delivered via Google form. Likes from students are depicted in figure 5, while the students' responses are tabulated in table 3 .

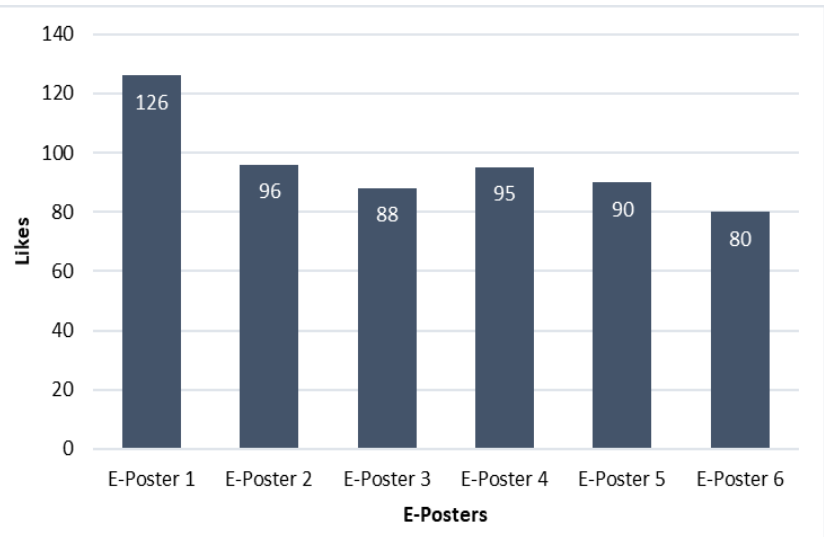

Figure 5. Likes on the posters on Instagram (Accessed: July 2019)

As a social media that puts forward the display of images and videos, Instagram is a platform that is loved by various groups, even teenagers and adults. Everyone can like a post if it suits their hobbies and habits. Figure 2 shows the number of likes obtained by each e-poster posted on the researcher's account. The number of likes was not significant because the post was very specific about the elemental material of the alkali metal. The account and related post is depicted in Figure 6.
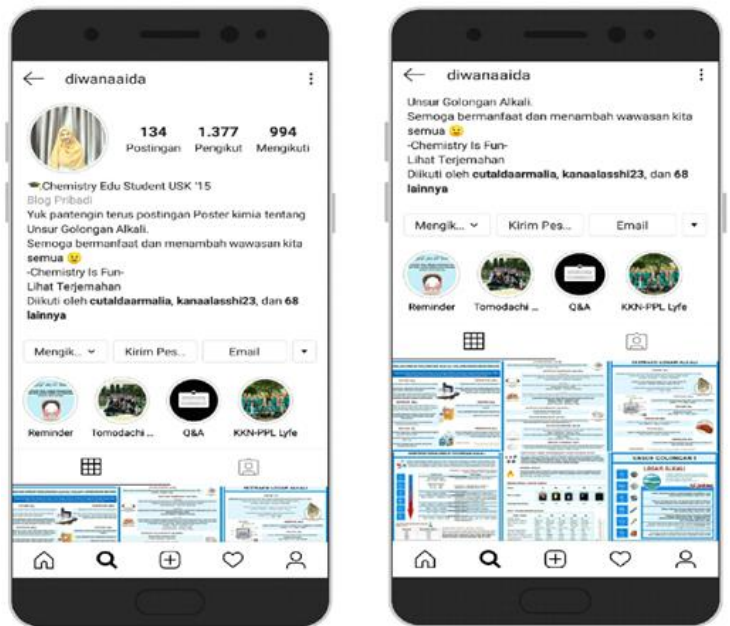

Figure 6. Screenshots of Instagram with e-posters posts.

Figure 6 shows the smartphone screenshots of the Instagram account associated with the development of e-poster in learning the concept of alkaline metal elements. We put six posters at the top post to make it easier for students to access and find the posters as they visit the profile. The students were given some days to access and study the materials before they were given the questionnaire. After one week, all students were asked to give their opinions regarding the e-poster quality and how the posters would possibly help and encourage them in learning.

Table 3. Students' responses toward e-posters

\begin{tabular}{|c|c|c|c|c|c|}
\hline \multirow[t]{2}{*}{ No } & \multirow[t]{2}{*}{ Statements } & \multicolumn{4}{|c|}{ Response (\%) } \\
\hline & & SA & $\mathrm{A}$ & DA & $\mathrm{SD}$ \\
\hline 1 & $\begin{array}{l}\text { I am interested in } \\
\text { using e-poster that } \\
\text { posted on Instagram }\end{array}$ & 70.8 & 25.0 & 0.0 & 4.2 \\
\hline 2 & $\begin{array}{l}\text { The posters have } \\
\text { proper text and } \\
\text { background color }\end{array}$ & 37.5 & 54.2 & 8.3 & 0.0 \\
\hline 3 & $\begin{array}{l}\text { The font used is } \\
\text { readable }\end{array}$ & 29.1 & 62.5 & 8.3 & 0.0 \\
\hline 4 & $\begin{array}{l}\text { The sentences used } \\
\text { were proper and } \\
\text { simple }\end{array}$ & 62.5 & 37.5 & 0.0 & 0.0 \\
\hline 5 & $\begin{array}{l}\text { The e-posters are easy } \\
\text { to use }\end{array}$ & 66.6 & 33.3 & 0.0 & 0.0 \\
\hline 6 & $\begin{array}{l}\text { The e-posters would } \\
\text { motivate me to study }\end{array}$ & 66.6 & 33.3 & 0.0 & 0.0 \\
\hline 7 & $\begin{array}{l}\text { I can learn } \\
\text { independently by } \\
\text { using e-posters }\end{array}$ & 50.0 & 50.0 & 0.0 & 0.0 \\
\hline 8 & $\begin{array}{l}\text { I think the posters are } \\
\text { really useful for me }\end{array}$ & 75.0 & 25.0 & 0.0 & 0.0 \\
\hline
\end{tabular}

$\mathrm{SA}=$ Strongly agree, $\mathrm{A}=$ Agree, $\mathrm{DA}=$ Disagree, $\mathrm{SD}=$ Strongly disagree

Table 3 illustrates the quality of e-posters from the students' point of view. The vast majority of students were interested in learning the desired material using Instagram-posted e-posters. Only a small portion $(4,2 \%)$ of students strongly disagree. Overall, the majority of students found that e-posters are useful, properly designed in terms of text, color, and image quality, and most of the students believed that the posters would be useful for enhancing their motivation and independence in learning.

Sari (2019) stated that social media could be the ultimate tool for students for autonomous learning. By using social media, students could practice learning while enjoying their time on a social media platform. Furthermore, social media is popular among the students in this era to readily incorporate and be familiar with social media platforms (Delello et al., 2015). Since most of the students usually spend most of their time with the smartphone (Nazar et al., 2018). However, social media is also distractive for students in achieving their goals in learning when not properly used for learning purposes. Therefore, lecturers or teachers need to design appropriate learning materials that benefit students in enhancing their learning outcomes.

\section{Research limitations}

We address some limitations of this research as follows: (1) The topic of the e-posters was specifically on the concept of alkaline group elements; (2) The app 
testing was conducted in a specific classroom. Thus the results of students' responses cannot be generalized; (3) The usability of the media has not been conducted. Only students' responses were recorded; (4) The language used in developing e-posters was Indonesian.

\section{Conclusion}

E-posters are visual media that are suitable for use as learning media because they can be posted on various social media platforms, especially Instagram. However, the development of e-posters for specific learning objectives must go through a needs analysis either by analyzing the curriculum or analyzing the need for the media by students as the center of learning. Students as the millennial generation have a more fondness and ability to use technology products so that they will adapt more quickly to current technology. This study proves that students prefer social media platforms as an intermediary for the delivery of knowledge, especially chemistry. Therefore, among recommendations, teachers must pay great attention to developing teaching materials, both learning resources or ICT-based learning media and social media, so that students could be more interested and motivated in learning.

\section{References}

Darici, A. (2016). The Importance of Needs Analysis in Materials Development. In A. Maryam, Z. Mitra, F. Akram, \& K. Hamid (Eds.), Issues in Materials Development (pp. 31-41). https://doi.org/10.1007/978-94-6300-432-9_3

Delello, J. A., McWhorter, R. R., \& Camp, K. M. (2015). Using social media as a tool for learning: A multidisciplinary study. International Journal on ELearning: Corporate, Government, Healthcare, and Higher Education, 14(2), 163-180.

Dellantonio, S., \& Pastore, L. (2020). Ignorance, misconceptions, and critical thinking. Synthese, (0123456789). https://doi.org/10.1007/s11229019-02529-7

Handayani, F. (2016). Instagram as a Teaching Tool? Really? Proceedings of the Fourth International Seminar on English Language and Teaching (ISELT-4), 320-327.

Ilic, D., \& Rowe, N. (2013). What is the evidence that poster presentations are effective in promoting knowledge transfer? A state-of-the-art review. Health Information and Libraries Journal, 30(1), 4-12. https://doi.org/10.1111/hir.12015

Irwandani, I., \& Juariyah, S. (2016). Pengembangan Media Pembelajaran Berupa Komik Fisika Berbantuan Sosial Media Instagram sebagai Alternatif Pembelajaran. Jurnal Ilmiah Pendidikan
Fisika Al-Biruni, 5(1), 33.

https://doi.org/10.24042/jpifalbiruni.v5i1.103

[Indonesian]

Jones, A. M. (2003). The use and abuse of PowerPoint in Teaching and Learning in the Life Sciences: A Personal Overview. Bioscience Education, 2(1), 1-13. https://doi.org/10.3108/beej.2003.02000004

Nazar, M., Muliana, R., \& Hanum, L. (2018). Smartphone Use and its Effects on the Student Final Grade ( a case study in the Environmental ChemistryClass ). Proceeding of the 2nd URICES, 978-979. Pekan Baru.

Nugroho, Restu, I., \& Ruwanto, B. (2017). The Development of Physics Learning Media Based on Social Media Instagram as Self Learning Resources to Improve Motivation and Achievement on Physics Learning of the Eleventh Grade Student of Senior High School. Jurnal Pendidikan Fisika, 6(6), 460-470.

Sari, R. (2019). Social Media As an Autonomous Learning Facility. English Language and Literature International Conference (ELLiC), 3(2), 296-301. Retrieved from https://jurnal.unimus.ac.id/index.php/ELLIC/a rticle/view/4729/4257

Sobah CH, S. N. S., Munawar, W., \& Hamdani, A. (2019). Eliminate Misconception in Learning. 299(Ictvet 2018), 416-418. https://doi.org/10.2991/ictvet18.2019 .94 